\title{
Effect of light and feeding on the nitrogen isotopic composition of a zooxanthellate coral: role of nitrogen recycling
}

\author{
S. Reynaud ${ }^{1, *}$, P. Martinez ${ }^{2}$, F. Houlbrèque ${ }^{1,3}$, I. Billy ${ }^{2}$, D. Allemand ${ }^{1}$, \\ C. Ferrier-Pagès ${ }^{1}$ \\ ${ }^{1}$ Centre Scientifique de Monaco, Avenue Saint Martin, 98000 Monaco, Principality of Monaco \\ ${ }^{2}$ Département de Géologie et Océanographie, UMR CNRS 5805-EPOC, Université Bordeaux I, Avenue des facultés, \\ 33405 Talence cedex, France \\ ${ }^{3}$ Geological \& Environmental Sciences Department, Stanford University, 450 Serra Mall, Bldg 320, Room 118, Stanford, \\ California 94305-2115, USA
}

\begin{abstract}
Experiments were performed in controlled conditions in order to investigate the effect of light and/or feeding on the $\delta^{15} \mathrm{~N}$ composition of zooxanthellae and animal tissue of a scleractinian coral, Stylophora pistillata. For this purpose, corals were cultured under 3 light levels $(80,200$, and $300 \mu \mathrm{mol}$ photons $\mathrm{m}^{-2} \mathrm{~s}^{-1}$ ) and for each light level, half of the corals were fed twice a week with natural zooplankton while the other half, the control group, were starved. To understand how plankton ingestion changes the isotopic signal of the corals, zooplankton $\delta^{15} \mathrm{~N}$ was also measured during the course of the experiment. It had a mean value of $6.75 \%$. No significant and consistent effect of light was observed on the $\delta^{15} \mathrm{~N}$ of the tissue or zooxanthellae of S. pistillata. However, there was a significant depletion in tissue and zooxanthellae ${ }^{15} \mathrm{~N}$ of fed corals compared to the controls. This depletion did not follow the general food-web rule in which predators are enriched in ${ }^{15} \mathrm{~N}$ by $3.5 \%$ compared to prey, but can be explained by the fact that nitrogen is recycled within the symbiotic association. Indeed, in heterotrophic organisms, the enrichment is due to light nitrogen $\left({ }^{14} \mathrm{~N}\right)$ being preferentially excreted in the form of waste products into the environment, which leads to an increase in the $\delta^{15} \mathrm{~N}$ signature of the animal. In corals, light waste products are instead recycled by the zooxanthellae, therefore depleting the isotopic signature of the zooxanthellae, and also of the host, by transfer of photosynthates with light nitrogen. These observations support the nitrogen-recycling rather than the nitrogen-conservation theory.
\end{abstract}

KEY WORDS: Stylophora pistillata $\cdot$ Corals $\cdot$ Nitrogen isotopic composition · Zooxanthellae · Tissues · Feeding $\cdot$ Culture

Resale or republication not permitted without written consent of the publisher

\section{INTRODUCTION}

Corals are mixotrophic organisms, able to fix inorganic carbon through the activity of their dinoflagellate symbionts, the zooxanthellae (Rahav et al. 1989, Muscatine 1990). They are also able to gain nutrients (such as nitrogen and phosphorus) from predation on plankton (e.g. Sebens et al. 1996, Ferrier-Pagès et al. 1998, Houlbrèque et al. 2003, Palardy et al. 2006) and uptake of dissolved organic (Al-Moghrabi et al. 1993,
Grover et al. 2006) or inorganic nutrients (Grover et al. 2003). Heterotrophy has been suggested not to represent a significant energy source for corals living in shallow waters but to become important for corals inhabiting deep or turbid waters, i.e. low-light environments (Muscatine \& Kaplan 1994, Anthony \& Fabricius 2000). Other observations, however, tend to support the idea that heterotrophy can be important at all depths and light environments (Muscatine \& Kaplan 1994, Houlbrèque et al. 2003, Palardy et al. 2006). Wit- 
ting (1999) also calculated that in situ zooplankton ingestion could represent a non-negligible energy input for the growth of 2 different scleractinian coral species, and Grottoli et al. (2006) showed that feeding rates on zooplankton largely increased in bleached corals compared to healthy ones and provided them with up to $100 \%$ of their daily metabolic demand, enabling them to maintain and/or restore energy reserves (Rodrigues \& Grottoli 2007). It was recently suggested that, in cnidarians, the simple autotrophic organic molecules were mainly used for respiration while the more complex heterotrophic organic molecules were used to build cellular structures such as proteins, nucleic acids, and membranes (Bachar et al. 2007).

Stable isotope analyses can bring new insights to the relative importance of auto-and heterotrophy, since they can be used to identify food sources (Peterson \& Fry 1987) and quantify carbon and nitrogen fluxes between different trophic levels (Minagawa \& Wada 1984, Rau et al. 1992). $\delta^{13} \mathrm{C}$ of consumers is usually similar to that of their diet, while $\delta^{15} \mathrm{~N}$ is enriched by 3 to $4 \%$ with each successive trophic level (DeNiro \& Epstein 1981, Rau et al. 1983, Owens 1988). While the $\delta^{13} \mathrm{C}$ signature of coral tissue and skeleton has been well studied under different trophic conditions (Felis et al. 1998, Grottoli \& Wellington 1999, Reynaud et al. 2002), far fewer studies have investigated the effects of feeding on the $\delta^{15} \mathrm{~N}$ signature of coral tissue, and results remain unclear. Muscatine and collaborators (Muscatine et al. 1989, Muscatine \& Kaplan 1994) were the first to investigate the effect of depth and availability of particulate organic matter on the nitrogen stable isotopes of coral tissue and zooxanthellae. Although the pattern was not always consistent, they reported depletion in heavy isotopes with depth. They deduced that corals living in deeper waters had lower photosynthetic rates and were more heterotrophic than corals living in shallow waters. From subsequent studies, it also appeared that several environmental parameters were affecting the $\delta^{15} \mathrm{~N}$ signature of coral tissue sampled in the field, such as inorganic nitrogen uptake (Yamamuro et al. 1995), terrestrial nitrogen loads (Sammarco et al. 1999), eutrophication (Sammarco et al. 1999, Heikoop et al. 2000a, Hoegh-Guldberg et al. 2004, Marion et al. 2006), zooxanthellar population dynamics (Heikoop et al. 2000b), light (Heikoop et al. 1998), and bleaching (Rodrigues \& Grottoli 2006).

The aim of the present study was to investigate, under controlled experimental conditions, the effect of light and/or feeding on the $\delta^{15} \mathrm{~N}$ of the zooxanthellae and coral tissue of Stylophora pistillata. Data obtained will help to understand results observed in previous in situ studies. For this purpose, several sets of corals were prepared and maintained, either starved or fed, at 3 different light levels. The effect of feeding on the carbon and oxygen isotopic composition of the tissue and skeleton of the same coral species under comparable controlled conditions has already been investigated (Reynaud et al. 2002). Feeding changed the $\delta^{13} \mathrm{C}$ isotopic signal of the coral tissue without changing the skeletal $\delta^{13} \mathrm{C}$ (Reynaud et al. 2002).

\section{MATERIALS AND METHODS}

Experimental set-up. The experiment was performed in the laboratory as described in Houlbrèque et al. (2003). During this experiment, both the physiological parameters and the isotopic signature of the tissue were monitored. The following methodology only refers to the isotope measurements. Six colonies of the branching scleractinian coral Stylophora pistillata Esper, 1797 were collected in the Gulf of Aqaba (Red Sea, Jordan), and maintained in aquaria. Terminal portions of branches were cut with bone-cutting pliers and ca. 90 nubbins (15 from each colony) were prepared. These fragments were then glued onto glass slides using underwater epoxy (Devcon ${ }^{\circledR}$ ) according to Reynaud-Vaganay et al. (1999), and randomly distributed into 6 independent aquaria (30 l) placed in a common water bath. The tanks were supplied with oligotrophic Mediterranean seawater (low amounts of organic and inorganic nutrients, no micro- or mesozooplankton, few bacteria and flagellates; Ferrier-Pagès et al. 1998) pumped from $50 \mathrm{~m}$ depth at a rate of $2 \mathrm{l} \mathrm{h}^{-1}$ and the water was continually mixed using a submersible pump (Minijet MN 606, Rena ${ }^{\circledR}$ ). Seawater was maintained at $26^{\circ} \mathrm{C}$. Light $\left(150 \mu \mathrm{mol}\right.$ photons $\left.\mathrm{m}^{-2} \mathrm{~s}^{-1}\right)$ was provided by metal halide lamps (Phillips HPIT, $400 \mathrm{~W}$ ) on a 12:12 h photoperiod. Temperature (precision: $\pm 0.1^{\circ} \mathrm{C}$ ) was logged at 10 min intervals using a Seamon ${ }^{\circledR}$ temperature recorder, and salinity and underwater irradiance were measured using a conductivity meter (Meter LF196) and a $4 \pi$ quantum sensor (Li-Cor, LI-193SA) respectively. Tanks were cleaned twice a week in order to prevent algae growth on the glass slides.

After a healing period of $3 \mathrm{wk}$, conditions were changed in the 6 independent tanks such that 3 different light levels $\left(80,200\right.$, and $300 \mu \mathrm{mol}$ photons $\mathrm{m}^{-2} \mathrm{~s}^{-1}$ ) and 2 feeding regimes (feeding and starving) for each light level as described in Houlbrèque et al. (2003) could be applied. An irradiance of $300 \mu \mathrm{mol}$ photons $\mathrm{m}^{-2} \mathrm{~s}^{-1}$ could be considered as a low value compared to the light measured in the field (up to $1200 \mu \mathrm{mol}$ photons $\mathrm{m}^{-2} \mathrm{~s}^{-1}$ at midday). However, under these experimental conditions, light was constant for $12 \mathrm{~h} \mathrm{~d}^{-1}$ and sufficient to reach maximal photosynthesis under these conditions (Ferrier-Pagès et al. 2000). For each light level, nubbins were either fed twice a week for $9 \mathrm{wk}$ or 
maintained starved for the entire incubation. Food supply was composed of natural and freshly collected zooplankton (ca. $1120 \pm 152$ organisms $\mathrm{l}^{-1}$ ), which is of a better nutritional value compared to prey cultivated in the laboratory, such as Artemia salina (Lasker et al. 1983, Zamer \& Hoffmann 1993). The ingestion of plankton by Stylophora pistillata was monitored in previous experiments (Ferrier-Pagès et al. 2003, Houlbrèque et al. 2003). Ingestion rates varied between 0.5 and 2 prey items polyp ${ }^{-1}$ in $1 \mathrm{~h}$ of ingestion, depending on the prey concentration (Sebens et al. 1996). The plankton was collected using a WP2 net and immediately brought back to the laboratory. It was first concentrated with a reverse filtration apparatus on a $10 \mu \mathrm{m}$ filter, to avoid including small algae and detritus. It was then added to seawater at $26^{\circ} \mathrm{C}$ and the actively swimming portion of the sample was fed to the corals. A $100 \mathrm{ml}$ sample was collected in the aquaria at each feeding time to determine the nature and abundance of the planktonic prey using a binocular $(40 \times)$ microscope and a Dolfuss chamber (Hydro-Bios). Adult and larval copepods represented the major fraction of this plankton. The rest was composed of siphonophores and different organisms such as brachiopod larvae, crustacean larvae, and jellyfishes. After feeding, the aquaria were entirely emptied, rinsed, and refilled with fresh seawater to stop the ingestion and avoid any contamination by dissolved organic nutrients.

After $9 \mathrm{wk}$, samples were treated as described in the next paragraph.

Sample preparation. All glassware was packed in aluminum foil and pre-combusted at $480^{\circ} \mathrm{C}$ for at least $6 \mathrm{~h}$ (Thermolyne 62700 oven). Each piece of coral was placed in a $100 \mathrm{ml}$ beaker containing $20 \mathrm{ml}$ of filtered seawater. Tissue was completely removed from skeleton with an air-pick (air under pressure) and homogenized with a Potter-Elvehjem tissue grinder. The homogenate was then centrifuged (Biofuge 17RSHeraeus) at $2800 \times g$ for $5 \mathrm{~min}$ at $4^{\circ} \mathrm{C}$ to pellet most of the zooxanthellae. The supernatant was centrifuged again at least twice at $2800 \times g$ for $10 \mathrm{~min}$ to pellet residual zooxanthellae (Muscatine et al. 1989), transferred into $50 \mathrm{ml}$ Pyrex tubes, and frozen $\left(-20^{\circ} \mathrm{C}\right)$ until subsequent analysis. Pellets of zooxanthellae were resuspended, washed 3 times with filtered seawater to avoid any tissue contamination, and frozen $\left(-20^{\circ} \mathrm{C}\right)$. Before isotopic measurements, tissue and zooxanthellar samples were freeze-dried using a Heto (CT 60) lyophilizer. In addition, $200 \mathrm{ml}$ of each plankton sample were filtered on a pre-combusted GF/F filter for isotopic signature measurement.

Stable isotope measurements. Nitrogen isotope $\left(\delta^{15} \mathrm{~N}\right)$ measurements were determined in animal tissue and zooxanthellar fractions as well as in plankton samples using a Carlo-Erba NA2500 Elemental Analyzer interfaced with an Isoprime-Micromass Stable Isotope Ratio Mass Spectrometer at EPOC, Université Bordeaux I. Isotopic analyses are reported according to the classical delta notation:

$$
\delta^{15} \mathrm{~N}=\left[\left(\mathrm{R}_{\text {sample }} / \mathrm{R}_{\text {standard }}\right)-1\right] \times 1000
$$

where $R={ }^{15} \mathrm{~N} /{ }^{14} \mathrm{~N}$, and all values are reported as per mille (\%o). The standard is atmospheric nitrogen. The precision of the measurements, expressed as the standard deviation from the mean replicate of international and laboratory standards, is better than $0.3 \%$.

Statistical analysis. We are aware that this experimental set-up is, strictly speaking, a pseudo-replicated design. However, it is almost impossible that differences in the tanks might have confounded the treatment effect. Indeed, it is clear from the physiological results obtained (Houlbrèque et al. 2003; significant and large increase in zooxanthellae density, in chlorophyll and protein contents, as well as in the rates of photosynthesis and calcification in fed compared to starved corals) that the tank effect, if any, was not significant compared to the feeding and light effects. Moreover, all parameters, such as temperature, light, and seawater renewal (and therefore salinity) were regularly measured and maintained at the desired values throughout the experiment. All these observations make us confident about the results obtained.

The cross-effect of light and feeding on the isotopic signature of coral host or zooxanthellae was assessed using 2-way ANOVAs. For each light level, the effect of feeding was again tested using a $t$-test. All statistical analyses were carried out using the statistical package STATVIEW 5.0.0.0. Results are reported as mean \pm standard error of the mean (SE) and $n$ is the sample size.

\section{RESULTS}

\section{Comparison between animal and zooxanthellae $\delta^{15} \mathrm{~N}$ signatures}

$\delta^{15} \mathrm{~N}$ values of the animal tissue were significantly higher $(7.65 \pm 0.09 \%$ o) than those of the zooxanthellae $(6.46 \pm 0.10 \%$, 1 -way ANOVA, p < 0.0001) for each light condition, and irrespective of feeding and starvation (Fig. 1). No correlation was found between the animal and zooxanthellae $\delta^{15} \mathrm{~N}$.

\section{Isotopic composition of coral tissue}

The 2-way ANOVAs testing the effects of light and feeding on the isotopic signature of the coral tissue showed a significant effect of feeding (Table 1, p = 


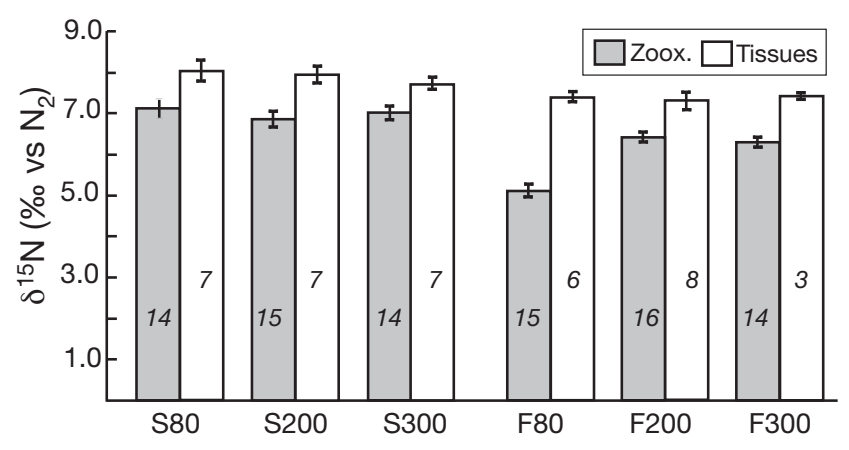

Fig. 1. Stylophora pistillata. $\delta^{15} \mathrm{~N}$ of zooxanthellae (Zoox.) and tissue fractions in each experimental condition. Three light levels were investigated $\left(80,200\right.$, and $300 \mu \mathrm{mol}$ photons $\mathrm{m}^{-2}$ $\mathrm{s}^{-1}$ ) and 2 feeding levels (S: starved and $\mathrm{F}$ : fed). Results are reported as mean \pm standard error of the mean (SE) and the sample size is the number in each bar of the histogram

Table 1. Stylophora pistillata. 2-way ANOVAs testing the effect of feeding and light on nitrogen isotopic composition, for coral tissue and zooxanthellae

\begin{tabular}{|c|c|c|c|}
\hline & $\mathrm{df}$ & $F$ & $\mathrm{p}$ \\
\hline \multicolumn{4}{|l|}{ Coral tissue } \\
\hline Feeding & 1 & 7.640 & 0.0094 \\
\hline Light & 2 & 0.177 & 0.8 \\
\hline Feeding $\times$ Light & 2 & 0.311 & 0.7 \\
\hline \multicolumn{4}{|l|}{ Zooxanthellae } \\
\hline Feeding & 1 & 63.387 & $<0.0001$ \\
\hline Light & 2 & 7.022 & 0.0015 \\
\hline Feeding $\times$ Light & 2 & 13.267 & $<0.0001$ \\
\hline
\end{tabular}

0.0094). The $\delta^{15} \mathrm{~N}$ values of the coral tissue (Fig. 2) were significantly lower in fed (mean: $7.36 \pm 0.11 \%$ ) than in starved corals (mean: $7.88 \pm 0.12 \%$ ). When compared for each light level, there was a significant difference between fed and starved corals maintained at 80 or $200 \mu \mathrm{mol}$ photons $\mathrm{m}^{-2} \mathrm{~s}^{-1}$ ( $t$-test, $\mathrm{p}=0.007$ and $\mathrm{p}=0.006$ respectively). However, corals cultivated at $300 \mu \mathrm{mol}$ photons $\mathrm{m}^{-2} \mathrm{~s}^{-1}$ did not show any difference between the 2 feeding regimes ( $t$-test, $p=0.4$ ).

Light had no significant effect on the $\delta^{15} \mathrm{~N}$ of the tissue (Fig. 2), either for fed or for starved corals (Table 1). The $\delta^{15} \mathrm{~N}$ values of coral tissue were $7.73 \pm 0.17,7.60 \pm$ 0.17 , and $7.62 \pm 0.14$ for corals cultured at 80,200 , and $300 \mu \mathrm{mol}$ photons $\mathrm{m}^{-2} \mathrm{~s}^{-1}$ respectively.

\section{Isotopic composition of zooxanthellae}

The 2-way ANOVAs showed a significant effect of feeding on the $\delta^{15} \mathrm{~N}$ values of zooxanthellae (Table 1 ,

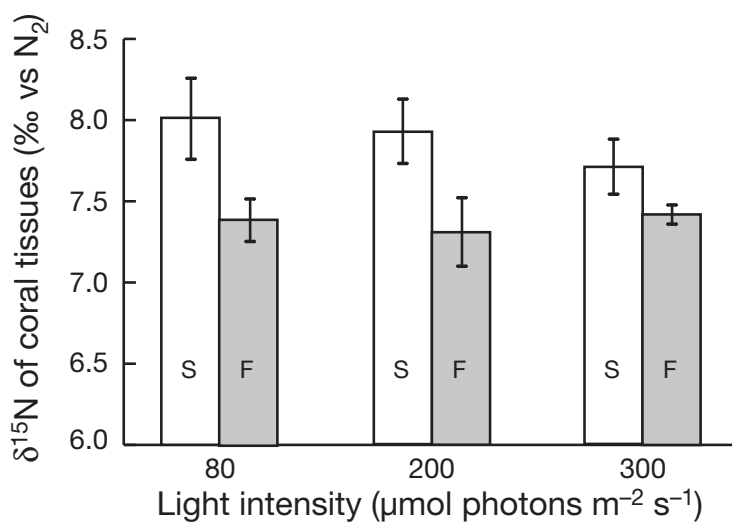

Fig. 2. Stylophora pistillata. $\delta^{15} \mathrm{~N}$ of tissues versus light intensity for starved $(\mathrm{S})$ and fed $(\mathrm{F})$ corals (mean $\pm \mathrm{SE}$ ). Sample sizes are as shown in Fig. 1

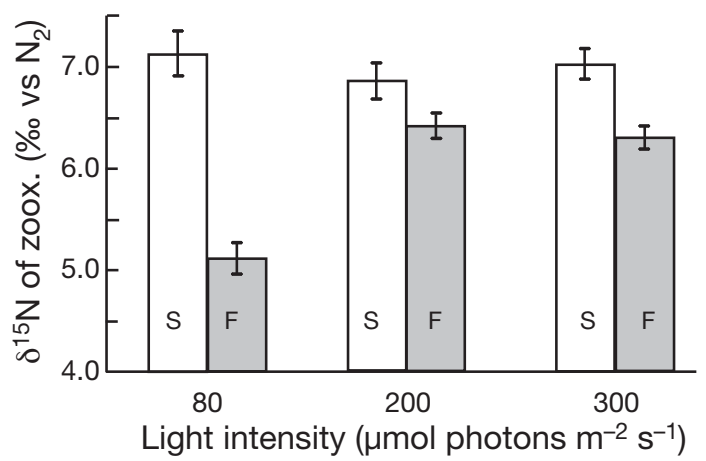

Fig. 3. Stylophora pistillata. $\delta^{15} \mathrm{~N}$ of zooxanthellae (zoox.) versus light intensity for starved $(\mathrm{S})$ and fed $(\mathrm{F})$ corals (mean \pm SE). Sample sizes are as shown in Fig. 1

$p<0.0001$, Fig. 3), ranging between $5.95 \pm 0.12$ and $7.00 \pm 0.11 \%$ for zooxanthellae from fed and starved corals. The $\delta^{15} \mathrm{~N}$ values of zooxanthellae from fed corals were $5.12 \pm 0.15,6.42 \pm 0.12$, and $6.30 \pm 0.12 \%$, and from starved corals were $7.12 \pm 0.22,6.86 \pm 0.18$, and $7.02 \pm 0.16 \%$, respectively for the 80,200 , and $300 \mu \mathrm{mol}$ photons $\mathrm{m}^{? 2} \mathrm{~s}^{\text {?1 }}$ light levels. Light also had a significant effect on the $\delta^{15} \mathrm{~N}$ of zooxanthellae (Table 1). There was also a crossed effect between light and feeding, because the effect of light was only significant on zooxanthellae from fed corals. Fed corals maintained under the lowest light level therefore presented a very low $\delta^{15} \mathrm{~N}$ signature compared to the others.

\section{Isotopic composition of prey}

$\delta^{15} \mathrm{~N}$ of the zooplankton was $6.75 \pm 0.90 \%$. The high variability was due to different prey compositions between samples. 


\section{DISCUSSION}

In the present study, the effect of light and feeding on the nitrogen isotopic composition of the animal tissue and zooxanthellae was investigated for the scleractinian coral Stylophora pistillata. The physiological differences between fed and starved colonies used in the present work are presented in Houlbrèque et al. (2003). In summary, after 9 wk of incubation, fed colonies had, at all light levels, much higher protein and chlorophyll concentrations (normalized per unit area of the coral), zooxanthellar densities, and calcification rates than starved colonies. Rates of photosynthesis expressed per skeletal surface area were also significantly higher in fed corals at 200 and $300 \mu \mathrm{mol}$ photons $\mathrm{m}^{-2} \mathrm{~s}^{-1}$ but remained unchanged between starved and fed corals when expressed per zooxanthella cell or amount of chlorophyll. Colonies maintained under the lowest light level $(80 \mu \mathrm{mol}$ photons $\mathrm{m}^{-2} \mathrm{~s}^{-1}$ ) had the lowest rates of photosynthesis, identical for fed and starved corals.

Results obtained with the starved corals showed a significant enrichment in $\delta^{15} \mathrm{~N}$ of the coral tissue compared to the zooxanthellae $(1 \%)$. This is in agreement with the observation that $\delta^{15} \mathrm{~N}$ is considered to be an indicator of the translocation of photosynthate from the zooxanthellae to the host. As a consequence, the host is generally enriched by $+1.5 \%$ compared to the zooxanthellae, due to an isotopic enrichment associated with the change in trophic level (Owens 1988). In the same way, Rodrigues \& Grottoli (2006) also concluded that the $\delta^{15} \mathrm{~N}$ of the coral host tissue was reflecting the zooxanthellae concentration. It has to be noted, however, that the $\delta^{15} \mathrm{~N}$ signature in the starved corals is in the upper range of the values measured by Muscatine et al. (2005) for symbiotic corals (from 3 to $7.6 \%$, see Fig. 1B in Muscatine et al. 2005) and in the range of mean values measured for asymbiotic corals (ca. $8.08 \%$ ). This large range of $\delta^{15} \mathrm{~N}$ values for symbiotic corals might originate from different organic and inorganic nitrogen sources found in seawater and taken up by the zooxanthellae.

Results obtained with the fed corals were, however, unexpected, but this is the first time that the effect of feeding has been experimentally tested on the coral $\delta^{15} \mathrm{~N}$ signature, with feeding being the unique parameter changing between experimental conditions. In pure animal systems, there is a $3.5 \%$ enrichment between each trophic level (Minagawa \& Wada 1984, Owens 1988), due to the fact that animals, after feeding, mainly excrete the light nitrogen isotope $\left({ }^{14} \mathrm{~N}\right)$, leading the heavy form $\left({ }^{15} \mathrm{~N}\right)$ to accumulate in the tissue. Conversely to this, and unexpectedly, fed coral tissue was not enriched in $\delta^{15} \mathrm{~N}$ compared to starved coral tissue, and was even depleted in most conditions. If we con- sider that the zooplankton supplied to corals presented a $\delta^{15} \mathrm{~N}$ of $6.75 \%$, and if we follow the isotopic trophic rules of $3.5 \%$ enrichment between trophic levels, fed coral tissue should have been enriched to a value of 9 to $10 \%$, which was not the case. Zooxanthellae from fed corals, especially those maintained at the lowest light level of $80 \mu \mathrm{mol}$ photons $\mathrm{m}^{-2} \mathrm{~s}^{-1}$, were also depleted in $\delta^{15} \mathrm{~N}$ compared to the ones from starved corals. If we also consider that a part of the organic food supplied to the host is directly and rapidly transferred to the symbionts (Piniak et al. 2003), zooxanthellae from fed corals should have also been enriched in ${ }^{15} \mathrm{~N}$ up to more than $10 \%$.

The lack of ${ }^{15} \mathrm{~N}$ enrichment of fed corals compared to other animals might certainly be due to the symbiotic status of these organisms, and to some patterns linked to the cycle of nitrogen in those symbioses. To date, this cycle has not been well established, and there are 3 theories, which are not always mutually exclusive. The first is the nitrogen-recycling theory, in which corals produce large amounts of ammonium in the form of waste products. This ammonium is not lost in the environment (Muscatine \& D'Elia 1978, Rahav et al. 1989) but assimilated into amino acids by algae and then released back to the animal (Wilkerson \& Muscatine 1984, Lipschultz \& Cook 2002). The second theory is the nitrogen-conservation hypothesis (Rees \& Ellard 1989, Wang \& Douglas 1998) in which nitrogen is retained in the animal host, which respires the photosynthates translocated by the algae rather than its amino acids. Finally, the third hypothesis of nitrogen limitation suggests a promotion of ammonium assimilation in the animal by alga-derived photosynthates (an extended review on these cycles can be found in Wang \& Douglas 1998). It has been suggested that nitrogen recycling is perhaps not very important in corals, yet results obtained in the present study suggest the contrary. Indeed, the recycling of nitrogen within the symbiotic association (light nitrogen of coral waste products transferred to the zooxanthellae) is a possible metabolic reason for the observed ${ }^{15} \mathrm{~N}$ depletion in zooxanthellae (Fig. 4). Since feeding should increase the amount of light nitrogen excreted (Rahav et al. 1989, Muscatine et al. 2005), it should increase the amount of light nitrogen flow into the zooxanthellae, leading to a depletion of the algae from fed corals compared to the algae from starved ones. This theory is strengthened by the results obtained with corals maintained at $80 \mu \mathrm{mol}$ photons $\mathrm{m}^{-2} \mathrm{~s}^{-1}$. These corals had the lowest photosynthetic rates (Houlbrèque et al. 2003) and should have therefore relied more on feeding for their metabolic needs, leading their zooxanthellae to be the most depleted compared to those from all other treatments (Fig. 3). This depletion could also have been increased by the low rates of photosynthe- 

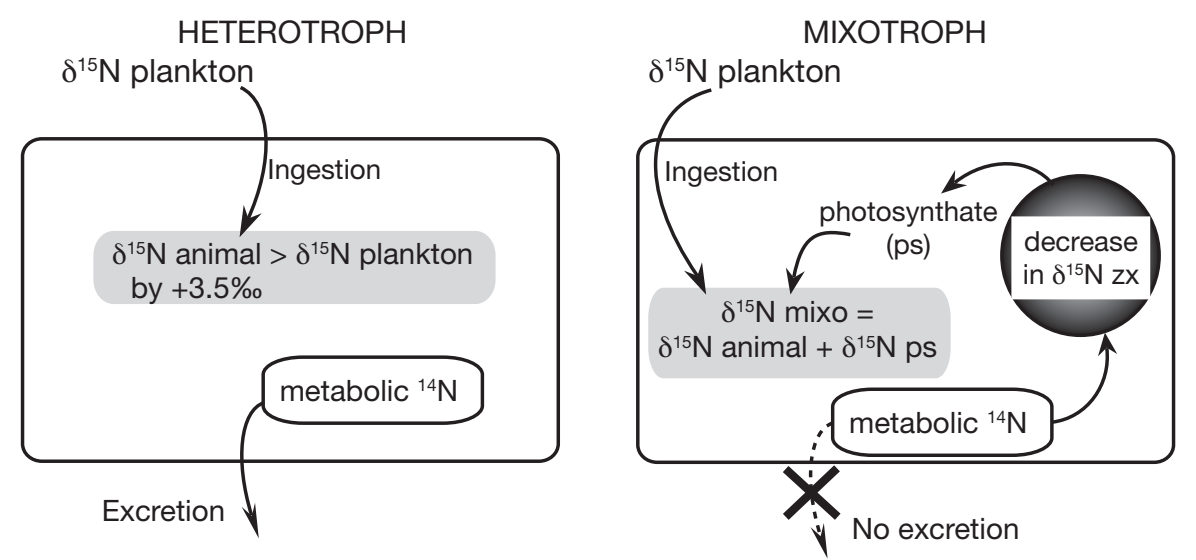

Fig. 4. Nitrogen pathway schematic for autotrophic and heterotrophic organisms (mean $\pm \mathrm{SE}$ ). mixo $=$ mixotroph; $\mathrm{zx}=$ zooxanthellae (see text for details)

sis, and a high discrimination towards light forms of inorganic nitrogen uptake (Wada \& Hattori 1976). It is unlikely that the growth rate of the algae could have had an effect on their nitrogen isotopic signature, since usually, fractionation is inversely proportional to growth rate (Muscatine \& Kaplan 1994). Multiplication of algae in fed corals (Houlbrèque et al. 2003) should have induced enrichment rather than depletion in ${ }^{15} \mathrm{~N}$, because rapidly growing cells usually need more dissolved inorganic nitrogen and present less discrimination.

Depletion in ${ }^{15} \mathrm{~N}$ of the coral tissue is in agreement with the observations of Muscatine \& Kaplan (1994), who also measured depletion with depth, and linked this depletion with the increased predation of corals on zooplankton. However, they did not measure the $\delta^{15} \mathrm{~N}$ signature of this zooplankton. It also supports the nitrogen-recycling theory, since in the 2 other theories, in which the animal tends to conserve nitrogen, animal tissue should be enriched and not depleted in ${ }^{15} \mathrm{~N}$. The depletion can be explained by the transfer of depleted zooxanthellar products to the host after assimilation of the host's waste ammonium. Treignier et al. (2008) also observed that feeding increased the total amount of lipid in coral tissue, without changing the lipid composition, because most of the food products were transferred from the host to the symbiont, re-transformed into the main algal lipid compounds, and given back to the host. The protein increase in fed corals (Houlbrèque et al. 2003), with a very low $\delta^{15} \mathrm{~N}$ signature $(2.9 \%$ for gorgonian skeletal protein, Ward-Paige et al. 2005 ; or $4 \%$ for coral skeletal organic matrix protein, Muscatine et al. 2005) could have enhanced the phenomenon.

Concerning the light parameter, no significant and consistent effect was noted on the $\delta^{15} \mathrm{~N}$ of the tissue or zooxanthellae of Stylophora pistillata. This contra- dicts the observations of Heikoop et al. (1998), who hypothesized that light could have a strong effect on corals from Jamaica. They indeed found depletion in ${ }^{15} \mathrm{~N}$ in 3 coral species (Montastrea annularis, Porites astreoides, and Agaricia agaricites) with depth and light attenuation, and concluded that light was the main parameter since they eliminated the effect of depth (and therefore increased heterotrophy). Indeed, deep corals were not enriched in ${ }^{15} \mathrm{~N}$ compared to surface ones, following the feeding rule of Minagawa \& Wada (1984). However, the range of light intensities used by Heikoop et al. (1998) was much larger than the range used in the present study, and the light intensities were also much higher, leading to the conclusion that more laboratory experiments, with light intensities ranging from 50 to $1000 \mu \mathrm{mol}$ photons $\mathrm{m}^{-2} \mathrm{~s}^{-1}$, are needed in order to ascertain the effect of light on the ${ }^{15} \mathrm{~N}$ signature.

This is the first experiment investigating the effect of feeding on the nitrogen isotopic composition of tissue and zooxanthellae of a scleractinian coral in controlled conditions. Most of the previous data were obtained on corals collected in situ, where several environmental parameters vary at the same time. The present paper therefore presents a new model explaining the $\delta^{15} \mathrm{~N}$ signatures of tissue and zooxanthellae in the scleractinian coral Stylophora pistillata (Fig. 4). Our data strongly suggest that the effect of feeding, although giving inverse trends compared to other animal systems, can indeed be studied in tropical corals.

Acknowledgements. Thanks are due to C. Emery and the boating staff of the Oceanographic Museum for plankton collection. The authors also thank 3 anonymous reviewers for their helpful comments, which improved the manuscript. This paper is dedicated to the memory of Professor L. Muscatine, who was one of the first to see the results of this experiment. 


\section{LITERATURE CITED}

Al-Moghrabi S, Allemand D, Jaubert J (1993) Valine uptake by the scleractinian coral Galaxea fascicularis: characterization and effect of light and nutritional status. J Comp Physiol B 163:355-362

Anthony KRN, Fabricius KE (2000) Shifting roles of heterotrophy and autotrophy in coral energetics under varying turbidity. J Exp Mar Biol Ecol 252:221-253

Bachar A, Achituv Y, Pasternak Z, Dubinsky Z (2007) Autotrophy versus heterotrophy: The origin of carbon determines its fate in a symbiotic sea anemone. J Exp Mar Biol Ecol 349:295-298

DeNiro MJ, Epstein S (1981) Influence of diet on the distribution of nitrogen isotopes in animals. Geochim Cosmochim Acta 45:341-351

Felis T, Pätzold J, Loya Y, Wefer G (1998) Vertical water mass mixing and plankton blooms recorded in skeletal stable carbon isotopes of a Red Sea coral. J Geophys Res Oceans 103:30731-30739

Ferrier-Pagès C, Allemand D, Gattuso JP, Jaubert J, Rassoulzadegan F (1998) Microheterotrophy in the zooxanthellate coral Stylophora pistillata. Limnol Oceanogr 43: $1639-1648$

Ferrier-Pagès C, Gattuso JP, Dallot S, Jaubert J (2000) Effect of nutrient enrichment on growth and photosynthesis on the scleractinian coral Stylophora pistillata. Coral Reefs 19:103-113

Ferrier-Pagès C, Witting J, Tambutté E, Sebens KP (2003) Effect of natural zooplankton feeding on the tissue and skeletal growth of the scleractinian coral Stylophora pistillata. Coral Reefs 22:229-240

Grottoli A, Wellington GM (1999) Effect of light and zooplankton on skeletal $\delta^{13} \mathrm{C}$ values in the eastern Pacific corals Pavona clavus and Pavona gigantea. Coral Reefs 18: $29-41$

Grottoli A, Rodrigues L, Palardy J (2006) Heterotrophic plasticity and resilience in bleached corals. Nature 440: $1186-1189$

Grover R, Maguer JF, Reynaud-Vaganay S, Ferrier-Pagès C (2003) Uptake of ammonium by the scleractinian coral Stylophora pistillata: effect of feeding, light, and ammonium concentrations. Limnol Oceanogr 48:2266-2274

Grover R, Maguer JF, Allemand D, Ferrier-Pagès C (2006) Urea uptake by the scleractinian coral Stylophora pistillata. J Exp Mar Biol Ecol 332:216-225

Heikoop JM, Dunn JJ, Risk MJ, Sanderman IM, Schwarcz HP, Waltho N (1998) Relationship between light and the $\delta^{15} \mathrm{~N}$ of coral tissue: examples from Jamaica and Zanzibar. Limnol Oceanogr 43:909?920

Heikoop JM, Dun JJ, Risk MJ, Tomascik T, Schwarz HP, Sandeman IM, Sammarco PW (2000a) Nitrogen-15 signals of anthropogenic nutrient loading in reef corals. Mar Pollut Bull 40:628-636

- Heikoop JM, Dun JJ, Risk MJ, McConnaughey TA, Sandman IM (2000b) Separation of kinetic and metabolic effect in carbon-13 records preserved in reef coral skeletons. Geochim Cosmochim Acta 64:975-987

Hoegh-Guldberg O, Muscatine L, Goiran C, Siggaard D, Marion G (2004) Nutrient-induced perturbations to $\delta^{13} \mathrm{C}$ and $\delta^{15} \mathrm{~N}$ in symbiotic dinoflagellates and their coral hosts. Mar Ecol Prog Ser 280:105-114

Houlbrèque F, Tambutté E, Ferrier-Pagès C (2003) Effects of zooplankton availability on the rates of photosynthesis, and tissue and skeletal growth in the scleractinian coral Stylophora pistillata. J Exp Mar Biol Ecol 296:145-166

Lasker HR, Gottfried MD, Coffroth MA (1983) Effects of depth on the feeding capabilities of two octocorals. Mar Biol 73: 73-78

Lipschultz F, Cook CB (2002) Uptake and assimilation of ${ }^{15} \mathrm{~N}-$ ammonium by the symbiotic sea anemones Bartholomea annulata and Aiptasia pallida: conservation versus recycling of nitrogen. Mar Biol 140:489-502

Marion GS, Hoegh-Guldberg O, McCulloch MT, Jupiter SD (2006) Coral isotopic records $\left(\delta^{15} N\right)$ of unprecedented land-use stress in Great Barrier Reef coastal communities. EOS Trans Am Geophys Union 87 (36) Ocean Sciences Meeting Suppl., Abstract OS520-04

- Minagawa M, Wada E (1984) Stepwise enrichment of ${ }^{15} \mathrm{~N}$ along food chains: further evidence and the relation between $\delta^{15} \mathrm{~N}$ and animal age. Geochim Cosmochim Acta 48:1135-1140

Muscatine L (1990) The role of symbiotic algae in carbon and energy flux in reef corals. In: Dubinsky Z (ed) Ecosystems of the world, coral reefs. Elsevier, New York, p 75-87

Muscatine L, D'Elia CF (1978) The uptake, retention and release of ammonium by reef corals. Limnol Oceanogr 23: 725-734

Muscatine L, Kaplan IR (1994) Resource partitioning by reef corals as determined from stable isotope composition. II. $\delta^{15} \mathrm{~N}$ of zooxanthellae and animal tissue versus depth. Pac Sci 48:304-312

Muscatine L, Porter JW, Kaplan IR (1989) Resource partitioning by reef corals as determined from stable isotope composition. I. $\delta^{13} \mathrm{C}$ of zooxanthellae and animal tissue vs depth. Mar Biol 100:185-193

- Muscatine L, Goiran C, Lynton L, Jaubert J, Cuif JF, Allemand D (2005) Stable isotopes $\left(\delta^{13} \mathrm{C}\right.$ and $\left.\delta^{15} \mathrm{~N}\right)$ of organic matrix from coral skeleton. Proc Natl Acad Sci USA 102:1525-1530

Owens NJP (1988) Natural variations in ${ }^{15} \mathrm{~N}$ in the marine environment. Adv Mar Biol 24:389-451

> Palardy JE, Grottoli A, Matthews KA (2006) Effect of naturally changing zooplankton concentrations on feeding rates of two coral species in the Eastern Pacific. J Exp Mar Biol Ecol 331:99-107

Peterson BJ, Fry B (1987) Stable isotopes in ecosystem studies. Annu Rev Ecol Syst 18:293-320

Piniak GA, Lipschultz F, McClelland J (2003) Assimilation and partitioning of prey nitrogen within two anthozoans and their endodymbiotic zooxanthellae. Mar Ecol Prog Ser 262:125-136

- Rahav OZ, Dubinsky Z, Achituv Y, Falkowski PG (1989) Ammonium metabolism in the zooxanthellate coral Stylophora pistillata. Proc R Soc Lond B 236:325-337

Rau GH, Mearns AJ, Young DR, Olson RJ, Schafer HA, Kaplan IR (1983) Animal ${ }^{13} \mathrm{C} /{ }^{12} \mathrm{C}$ correlates with trophic level in pelagic food webs. Ecology 64:1314-1318

$>$ Rau GH, Ainley DG, Bengtson JL, Torres JJ, Hopkins TL (1992) ${ }^{15} \mathrm{~N} /{ }^{14} \mathrm{~N}$ and ${ }^{13} \mathrm{C} /{ }^{12} \mathrm{C}$ in Weddell sea birds, seals, and fish: implications for diet and trophic structure. Mar Ecol Prog Ser 84:1-8

Rees TAV, Ellard FM (1989) Nitrogen conservation and the green hydra symbiosis. Proc R Soc Lond B 236:203-212

Reynaud S, Ferrier-Pagès C, Sambrotto R, Juillet-Leclerc A, Jaubert J, Gattuso JP (2002) Effect of feeding on the carbon and oxygen isotopic composition in the tissues and skeleton of the zooxanthellate coral Stylophora pistillata. Mar Ecol Prog Ser 238:81-89

Reynaud-Vaganay S, Gattuso JP, Cuif JP, Jaubert J, JuilletLeclerc A (1999) A novel culture technique for scleractinian corals: application to investigate changes in skeletal $\delta^{18} \mathrm{O}$ as a function of temperature. Mar Ecol Prog Ser 180: $121-130$ 
Rodrigues L, Grottoli A (2006) Calcification rate, and the stable carbon, oxygen and nitrogen isotopes in the skeleton, host tissue and zooxanthellae of bleached and recovering Hawaiian corals. Geochim Cosmochim Acta 70:2781-2789

Rodrigues L, Grottoli A (2007) Energy reserves and metabolism as indicators of coral recovery from bleaching. Limnol Oceanogr 52:1874-1882

Sammarco PW, Risk MJ, Schwarcz HP, Heikoop JM (1999) Cross-continental shelf trend in coral $\delta^{15} \mathrm{~N}$ on the Great Barrier Reef: further consideration of the reef nutrient paradox. Mar Ecol Prog Ser 180:131-138

Sebens KP, Vandersall KS, Savina LA, Graham KR (1996) Zooplankton capture by two scleractinian corals, Madracis mirabilis and Montastrea cavernosa in a field enclosure. Mar Biol 127:303-317

Treignier C, Grover R, Tolosa I, Ferrier-Pagès C (2008) Effect of light and feeding on the fatty acid and sterol composition of zooxanthellae and host tissue isolated from the scleractinian coral Turbinaria reniformis. Limnol Oceanogr 53:2702-2710

Wada E, Hattori A (1976) Natural abundance of ${ }^{15} \mathrm{~N}$ in partic-

Editorial responsibility: Matthias Seaman,

Oldendorf/Luhe, Germany ulate organic matter in the North Pacific Ocean. Geochim Cosmochim Acta 40:249-251

Wang JT, Douglas AE (1998) Nitrogen recycling or nitrogen conservation in an alga-invertebrate symbiosis? J Exp Biol 201:2445-2453

Ward-Paige CA, Risk MJ, Sherwood OA (2005) Reconstruction of nitrogen sources on coral reefs: $\delta^{15} \mathrm{~N}$ and $\delta^{13} \mathrm{C}$ in gorgonians from Florida reef tract. Mar Ecol Prog Ser 296: 155-163

Wilkerson FP, Muscatine L (1984) Uptake and assimilation of dissolved inorganic nitrogen by a symbiotic sea anemone. Proc R Soc Lond 221:71-86

Witting JH (1999) Zooplankton capture and coral growth: the role of heterotrophy in Caribbean reef corals. PhD thesis, Northeastern University, Boston, MA

Yamamuro M, Kayanne H, Minagawa M (1995) Carbon and nitrogen stable isotopes of primary producers in coral reef ecosystems. Limnol Oceanogr 40:617-621

Zamer WE, Hoffmann RJ (1993) Pyruvate metabolism in laboratory-acclimated and freshly collected sea anemones, Metridium senile L. J Exp Mar Biol Ecol 171:23-37

Submitted: February 10, 2009; Accepted: July 2, 2009

Proofs received from author(s): September 4, 2009 